\title{
Effect Of Thinking Aloud Pair Problem Solving Type Cooperative Model On Student Problem- Solving Ability
}

\author{
$1^{\text {st }}$ Sri Hayatun Nufus \\ Mathematics Department \\ Universitas Negeri Padang \\ Indonesia \\ srihayatunnufus17@gmail.com
}

\author{
$2^{\text {nd }}$ I Made Arnawa \\ Mathematics Department \\ Universitas Andalas \\ Indonesia \\ arnawa1963@gmail.com
}

\begin{abstract}
This study aims to determine the effect of type cooperative model Thinking Aloud Pair Problem Solving on students' problem solving abilities. This study was a quasiexperimental study with the randomized group only design. The research subjects were students of SMPN 1 Sungai Tarab district in the 2018/2019 school year. Sampling was done randomly after testing for normality, homogeneity, and average similarity. The instrument used is a problem solving test. From the results of research conducted shows the ability of problem solving students of experimental class is better than the control class. Thus the type cooperative model Thinking Aloud Pair Problem Solving contributes to students' problem solving.
\end{abstract}

Keywords-thinking aloud pair problem solving, problem solving

\section{INTRODUCTION}

In the 2013 curriculum the purpose of learning mathematics includes three aspects, namely attitudes, skills, and knowledge. One aspect of knowledge is the ability to solve problems. Suherman et al in [1] said that problem solving part of the mathematics curriculum that is important in the learning process and its completion, students are likely to obtain knowledge and skills in routine problem solving. Pehkonen in [2] also explained that the problem-solving abilities of students are expected to develop students' cognitive skills, encourage creativity, and motivate students to learn mathematics. So problem solving ability is very important in learning mathematics.

Students' problem solving ability is still relatively low $[3,4]$. This was also found by researchers at SMPN 1 Sungai Tarab. Developing these capabilities is one of them by applying a learning model that makes the atmosphere conducive. Many researchers have conducted research on these problem solving abilities, including [4, $5,6,7]$. One model that can be applied to improve these abilities is thinking aloud pair problem solving (TAPPS). TAPPS learning model can improve students' problem solving $[6,8,7,5]$.

According to Wah TAPPS is a problem-solving learning model that involves students in groups, where each group has a problem solver and there is a listener [6]. Jeon in [5] explained that "thinking is a problem solving pair that is manly based on thinking aloud and listening". Thinking according to Reason in [9] is a mental process of someone who is more than just remembering and understanding. Thinking aloud is thinking while saying or conveying what is being thought hard.

From the description above, the researchers want to see the extent to which the TAPPS type of cooperative learning model influences students' problem solving abilities. There are 4 problem solving steps seen, namely, (1) understanding the problem, (2) making plans, (3) implementing the plan, (4) checking back [10]. Therefore a research was carried out with the title "The Effect of the Application of the TAPPS Cooperative Learning Model on the Problem Solving Ability of Class VII Students of SMPN 1 Sungai Tarab District". This research was conducted to find out the problem solving ability of students who learn with the TAPPS type cooperative model and students who learn with conventional learning. The hypothesis of this study is the problem solving ability of students who learn with the TAPPS type cooperative model is higher than the problem solving ability of students who learn with conventional learning.

\section{METHODS}

The population of this study was 7 th grade students of SMPN 1 Sungai Tarab in 2018/2019 academic year consisting of 5 classes. Sampling was taken randomly, which was chosen in class $7 \mathrm{~A}$ as an experimental class with 26 students and $7 \mathrm{~B}$ as a control class with 25 students. Independent variable in this study is the TAPPS type cooperative learning model and the dependent variable of students' problem solving ability.

This type of research is a quasi-experimental research with TRGCOD design, which can be seen in Table I .

TABLE 1. RANCANGAN THE RANDOMIZED CONTROL GROUP ONLY

\begin{tabular}{|c|c|c|}
\multicolumn{3}{|c|}{ DESIGN } \\
\hline Group & Treatment & Test \\
\hline Experiment & $\mathrm{X}$ & $\mathrm{O}$ \\
\hline Control & $\mathrm{Y}$ & $\mathrm{O}$ \\
\hline
\end{tabular}

Description:

$\mathrm{X}=$ Thinking aloud pair problem solving type cooperative model

$\mathrm{Y}=$ Conventional learning

$\mathrm{O}=$ Test problem solving

Research data was collected by tests. This test is used to measure students' problem solving abilities. Tests that have been validated by the validator will be tested in class 
7 to see the validity and reliability of the questions. Scores of students' problem solving abilities are determined according to [10].

\section{RESUlT AND DISCUSSION}

Students' understanding of the material that has been given can be seen from student learning outcomes [11]. The test given to students is a test of problem solving ability. After the tests in the experimental class and control class obtained data about the results of problem solving tests which can be seen in Table II.

TABle II. Results Ability Test PROBlem Solving Student

\begin{tabular}{|c|c|c|c|c|c|}
\hline \multirow{2}{*}{$\begin{array}{c}\text { Class/Initial } \\
\text { Ability }\end{array}$} & \multicolumn{5}{|c|}{ Problem Solving Ability } \\
\cline { 2 - 6 } & $\mathbf{N}$ & $\overline{\boldsymbol{x}}$ & $\begin{array}{c}\text { Standard } \\
\text { Deviation }\end{array}$ & $\begin{array}{c}\text { Xmak } \\
\text { S }\end{array}$ & $\begin{array}{c}\text { Xmi } \\
\mathbf{n}\end{array}$ \\
\hline Experimental & 26 & 9,7 & 3,8 & 14 & 2 \\
\hline Control & 25 & 3,8 & 1,8 & 8 & 2 \\
\hline
\end{tabular}

From Table 2. can be seen the average value of the experimental class is higher than the control class average. The average value of the experimental class was 9.7 and the average control class was 1.8. This means that the test results of problem solving abilities in the experimental class are higher than the control class.

The percentage of troubleshooting values according to the troubleshooting steps can be seen from the following Table III:

Table III. Percentage of Student Problem Solving

\begin{tabular}{|c|c|}
\hline TABLE III. PERCENTAGE OF STUDENT PROBLEM SOLVING \\
\hline Problem Solving Steps & $\mathbf{\%}$ \\
\hline Understand the problem & 96,23 \\
\hline Make a plan & 35,26 \\
\hline Implement the plan & 20,83 \\
\hline Check back & 1,92 \\
\hline
\end{tabular}

From Table III. It can be seen that the highest percentage of students is in the ability of students to understand the problem. The lowest percentage is the ability of students to check the answers obtained by students.

\section{a. Understand the problem}

Students' understanding of the given problem reaches $69.23 \%$, where each question given students is able to write down what is known and what is asked of the problem.

\section{b. Make a plan}

In this step, students have been able to plan a problem solving strategy that reaches $35.26 \%$.

\section{c. Implement the plan}

In this step, the percentage of students only reached $20.83 \%$. There are still students who are less able to implement the planned strategic plan. This can be seen from figure 2. Students cannot implement the plan or strategy that has been written.

\section{d. Check back}

In the step of checking again the percentage of students is $1.92 \%$. Generally students do not check the answers that have been written. Students only focus on the final results without looking back at the right or wrong answers they get.

To find out the test used in hypothesis testing, the normality test and homogeneity test were carried out with the help of SPSS software.

\begin{tabular}{|c|c|}
\multicolumn{2}{|c|}{ TABLE IV. NORMALITY TEST } \\
\hline Sample Class & Sig. \\
\hline Experimental & 0,002 \\
\hline Control & 0,005 \\
\hline
\end{tabular}

Table.IV shows that the two sample classes have a value of Sig $<0.05$ so it can be concluded that the sample value is not normally distributed. Data that is not normally distributed does not need to be tested for homogeneity, so it is continued with the Mann-Whitney test.

\begin{tabular}{|c|c|}
\hline TABLE V. RESULTS PROBLEM SOLVING HYPOTHESIS TEST \\
\hline Ability & Sig. \\
\hline Problem Solving & 0,000 \\
\hline
\end{tabular}

The results of testing the hypothesis in Table $\mathrm{V}$ shows that the value of Sig $<0.05$. So that it can be declared reject $\mathrm{H}_{0}$, namely the problem-solving ability of students who learn with the TAPPS type cooperative model is higher than the problem solving ability of students who learn with conventional learning.

\section{CONCLUSIONS}

Based on the results of research conducted in 7A and 7B classes at SMPN 1 Sungai Tarab, it can be concluded that students 'problem-solving abilities who learn with the TAPPS type cooperative model are higher than students' problem solving abilities who learn with conventional learning. Thus, it is evident that the TAPPS type cooperative model contributes to students' problem solving abilities.

\section{REFERENCES}

[1] Suherman. Erman, et al, Strategi Pembelajran Matematika Kontemporer, Bandung: JICA Universitas Pendidikan Indonesia., 2003.

[2] Alimuddin, "Menumbuh Kembangkan Kemampuan Berfikir Kreatif Siswa melalui Tugas-Tugas Pemecahan Masalah", Proseding Seminar Nasional Penelitian, Pendidikan dan Penerapan MIPA. Fakultas MIPA, Universitas Negeri Yogyakarta, 2009.

[3] Siswono. TYE, "Upaya Meningkatkan Kemampuan Berfikir Kreatif Siswa melalui Pengajuan Masalah”, Jurnal Terakreditasi, Jurnal Pendidikan Matematika dan Sains, Tahun X, No. 1, ISSN 1410-1866, pp. 1-9, FMIPA: Universitas Negeri Yogyakarta, 2005.

[4] Afriansyah. Ekasatya A, "Peningkatan Kemampuan Pemecahan Masalah Siswa dengan Menerapkan Model Pembelajaran Problem Based Learning dan Inquir", Jurnal Pendidikan Matematika vol. 7 ISSN 2086 4280, 2016.

[5] Kani. NHA, \& Shahrill. Masitah, "Applying the Thinking Aloud Pair Problem Solving Strategy in Mathematics Lessons", Asian Journal of Management Sciences and Education, ISSN: 21868441 vol. 4, 2015.

[6] Wulandari. Nur Arum "Pengembangan Karakter dan Pemecahan masalah melalui Pembelajaran Matematika dengan model TAPPS", Unnes Journal of Mathematics Education, ISSN NO 2252-6927, 2013.

[7] Rahmat. Maulidi, et al, "Kemampuan Pemecahan Masalah Melalui Strategi Pembelarajaran Thining Aloud Pair Problem Solving Siswa Kelas X SMA", Jurnal Fisika Indonesia No.54, Vol XVIII, ISSN : 1410-2994, 2014. 
[8] Astuti. Robia, et al, "Eksperimentasi Model Pembelajaran Kooperatif Tipe TAPPS dan TSTS terhadap Kemampuan Menyelesaikan Soal Cerita Matematika ditinjau dari Tipe Kepribadian", Journal Elektronik Pembelajaran Matematika, ISSN: 2339-1685 vol.2, pp. 399-410, 2014.

[9] Sanjaya. Wina, Strategi Pembelajaran Berorientasi Standar Proses Pendidikan, Jakarta: Kencana Prenada Media Group, 2006.

[10] Polya. G, How To Solve It: New Aspect Of Mathematical Method. Pricenton: University Press, 1973.

[11] Nasution. S, Berbagai Pendekatan dalam Proses Belajar Mengajar, Jakarta: Bumi Aksara, 2000 